\title{
Modality, Modal Commitment and Modal Responsibility of the Speeches Delivered by the President of Sri Lanka at the UNO General Assembly: A Systemic Functional Analysis
}

Upul Priyantha Gamage

(BA, MA, a Ph.D. candidate at the Central China Normal University), Lecturer, Faculty of Language Studies, The Buddhist and Pali University of Sri Lanka

E-mail: gamageup@gmail.com

Patrick Sadi Makangila (Corresponding author)

(BA, MA, a Ph.D. candidate at the Central China Normal University).

E-mail: 3159632708@qq.com

Received: August 31, 2019 Accepted: September 20, 2019 Published: September 22, 2019

doi:10.5296/jsel.v7i1.15501 URL: https://doi.org/10.5296/jsel.v7i1.15501

\begin{abstract}
The main aim of this paper is to unpack the types of modality used, and their level of commitment and responsibility in the selected sample. Also, this study scrutinizes the frequency of occurrence of modal expressions by employing the Systemic Functional Linguistic approach. As was found out, the first case does not reflect a higher frequency of modal expressions, but in the second case, it remains in a higher percentage by showing the commitment of the speaker towards the propositions and proposal of the speeches. Apart from typical modal verbal operators, the study found a considerable number of other modal expressions such as different mood adjuncts and adjectival expressions over the two speeches which also have been used to persuade the listeners of his assembly. The speaker's commitment to the validity of messages is obviously manifested in both cases of the present study which illustrates how important modality in political discourse.
\end{abstract}

Keywords: modality, mood adjuncts, modal operators, modal commitment, modal responsibility 


\section{Introduction}

Language is a meaning potential according to Systemic Functional Linguistics (SFL), and also it is a system of choices (Thompson, 2014; Halliday, Halliday, 2007; Halliday, 2005). Modality is one such system within the language which has been given different interpretations in the functional approach itself. Role and Reference Grammar, Functional Grammar and the Cognitive Functional Approach are some such different theoretical conventions apart from Systemic Functional Linguistics which have given explanations for modality in different stances. Systemic Functional Linguistics has given a comprehensive explanation of modality and this analysis is done based on the SFL approach which has fundamentally been developed by M. A. K. Halliday and followers.

\section{Method and Objectives}

The aim of this paper is to analyze the two consecutive speeches delivered by the president of Sri Lanka at the general assembly of the UNO by using the approach of Systemic Functional Linguistics in order to examine the types of modality used and their level of commitment and responsibility in these speeches. Also, this study looks at the frequency of occurrence of modal expressions in this selected discourse. The data we have used for this analysis was derived from the official website of the Sri Lankan president and the United Nations Organization's official website. Only two consecutive speeches delivered by the president of Sri Lanka at the UNO general assembly are used and they are also freely available on several other websites as videos and texts. The two speeches of consecutive years are 2016 and 2017, respectively at the $71^{\text {st }}$ and $72^{\text {nd }}$ sessions of the UNO general assembly. The two scripts of the speeches were subtly scrutinized based on the SFL approach while trying to give some sort of a quantitative explanation as well. It is said that the $71^{\text {st }}$ and $72^{\text {nd }}$ speeches are promising in terms of persuading the international community towards the political sustainability of the country and modality in language can account for persuasion at various levels. The modality system also indicates the way that the speaker's judgment of probabilities and obligations signals factuality, certainty, and doubt are conveyed through his/her use of language (Chaiyasat \& Sudajit-apa, 2017; Dickinson, 2009). This is one rationale to select these two speeches for the present study. The selected sample for the present study could be considered as a political discourse.

\section{Modality, Modal Commitment, and Modal Responsibility}

Typically, the modality realizes through modal verbs in English, but some scholars have recognized a range of modal expressions beyond the modal verbs. The list consists of semi-auxiliaries, adjectival, participle and nominal modal expressions, modal adverbs, and lexical verbs (Perkins, 1983). In this sense, the modality has become a linguistic category referring to the factual status of a state of affairs (De Hoop \& Lestrade, 2015). But, still, the wide-ranging account on modality is the Systemic Functional Linguistic account by Halliday. To understand the modality in SFL, understanding polarity is some sort of a prerequisite. 
Polarity is thus a choice between 'yes' and 'no'. But these are not the only possibilities; there are intermediate degrees, various kinds of indeterminacy that fall in between, such as 'sometimes 'or 'maybe'. These intermediate degrees, between the positive and negative poles, are known collectively as MODALITY. What the modality system does is to construe the region of uncertainty that lies between 'yes' and 'no' (Matthiessen, Teruya \& Lam, 2010; Halliday\& Matthiessen, 2004). This has further been simplified by Thompson; the Finite must be formally positive or negative. However, semantically there are also intermediate stages - points between 'yes' and 'no' such as 'maybe' or 'sometimes' or 'supposedly' - that are expressed by modality. A simple starting definition of modality is that it is the space between 'yes' and 'no' (Thompson, 2014). It has been identified in two directions; Modality means likely or unlikely (if a proposition), desirable or undesirable (if a proposal) (Halliday \& Matthiessen, 2004).

To gain a fuller view of modality, we need to return to the distinction in speech roles in the language. If the commodity being exchanged is information, we can refer to the utterance as a proposition. In such cases, the modality relates to how valid the information is being presented as in terms of probability (how likely it is to be true) or usuality (how frequently it $i$ $\mathrm{s}$ true). Some of the basic points on the probability scale are: possible/probable/certain; on the usuality scale, they include: sometimes/often/always. If, on the other hand, the commodity is goods-\&-services, we can call the utterance a proposal; and then the modality relates to how confident the speaker can appear to be in the eventual success of the exchange. In commands, this concerns the degree of obligation on the other person to carry out the command (the scale for the demanded goods-\&-services includes: permissible/advisable/obligatory), while in offers it concerns the degree of willingness or inclination of the speaker to fulfill the offer (the speaker may signal: ability/willingness/determination). In order to distinguish these two basic types of modality, the first is called modalization, whereas the second is referred to as modulation (Thompson, 2014; Webster, 2009). With modality the dimension is that of assessment: modality construes a region of uncertainty where I can express, or ask you to express, an assessment of the validity of what is being said (Halliday \& Matthiessen, 2004). Modality has also been given some narrow definitions as well; Modality in a narrow sense is referred to as Engagement and defined as "a system of options" "to indicate the speaker's degree of commitment to the appraisal being expressed, and is expressed through modality and related systems". Of course, this kind of explanation came into being after the new theoretical formation of appraisal by Martin and White (2005). Apart from the SFL approach, there are other several approaches to classifying 'modality' such as epistemic and non-epistemic modality (Lycan, 1994; Anicic, n.d.). Thus the Finite element, as well as expressing primary tense or modality, also realizes either positive or negative polarity. Modality can thus be seen as constructing a kind of interpersonal 'aura' of the speaker's attitude around the proposition (Thompson, 2014; Milkovich \& Sitarica, 2017). MODALITY can thus be considered as the speaker's judgment, or request of the judgment of the listener, on the status of what is being said (It could be. Couldn't it be? You mustn't do that. Must you do that?) (Haliday, 2004). In most cases, a modal operator expresses the speaker's attitude at the time of speaking according to Thompson (2014). The speaker may signal a higher or lower degree of certainty about the validity of proposition or higher or lower degree of pressure on the other to carry 
out a command (high, median or low value). The basic distinction that determines how each type of modality will be realized is the ORIENTATION: that is, the distinction between subjective and objective modality, and between the explicit and implicit variants (Halliday \& Matthiessen, 2004). The term 'implicit' is used when the modality is expressed in the same clause as the main proposition, while 'explicit' is used when it is expressed in a separate clause.

Now it is clear that modality is used to show the uncertainty as well. There are many reasons why someone may wish to appear uncertain through modality (Thompson, 2014). As we have already pointed out, the modality has been discussed in a comprehensive manner and it has several subdivisions. Modal commitment and modal responsibility are two such divisions that we are going to explore in the present work. Modal commitment is the degree to which the speaker commits herself to the validity of what she is saying (Thompson, 2014). Modal responsibility - One feature that the different realizations of modality have in common is that they can be graded according to how far the speaker overtly accepts responsibility for the attitude being expressed (Thompson, 2014). Below is the very simple version of the modality network with its sub-divisions.

Figure 1

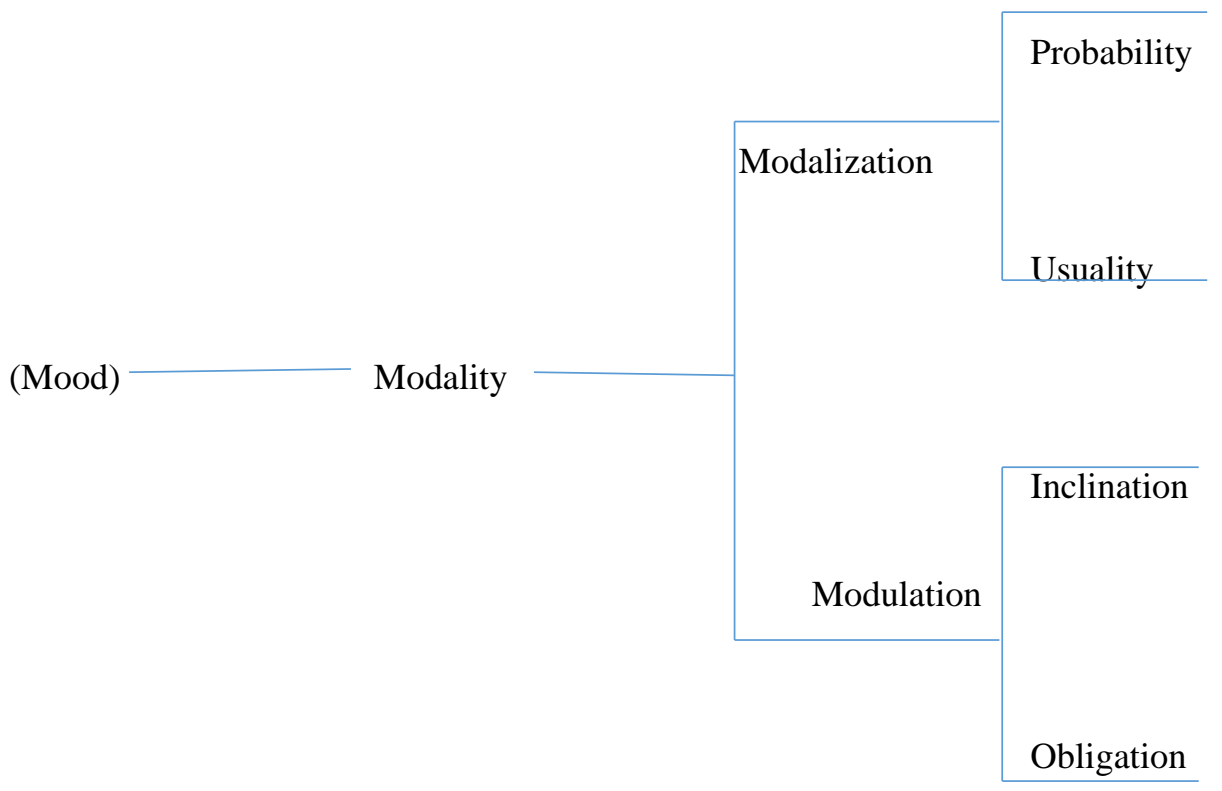

\subsection{Simplified System Network for Modality}

As we have highlighted, the modality has very comprehensively been explored in the latest version of Halliday's functional grammar (2004). According to that explanation, based on the type of modality, it has one dimension, whereas orientation, value, and polarity have given three more dimensions. Based on this comprehensive explanation, below is the system 


\section{Macrothink}

network introduced by Halliday in the third version of 'An Introduction to Functional Grammar'.

Figure 2

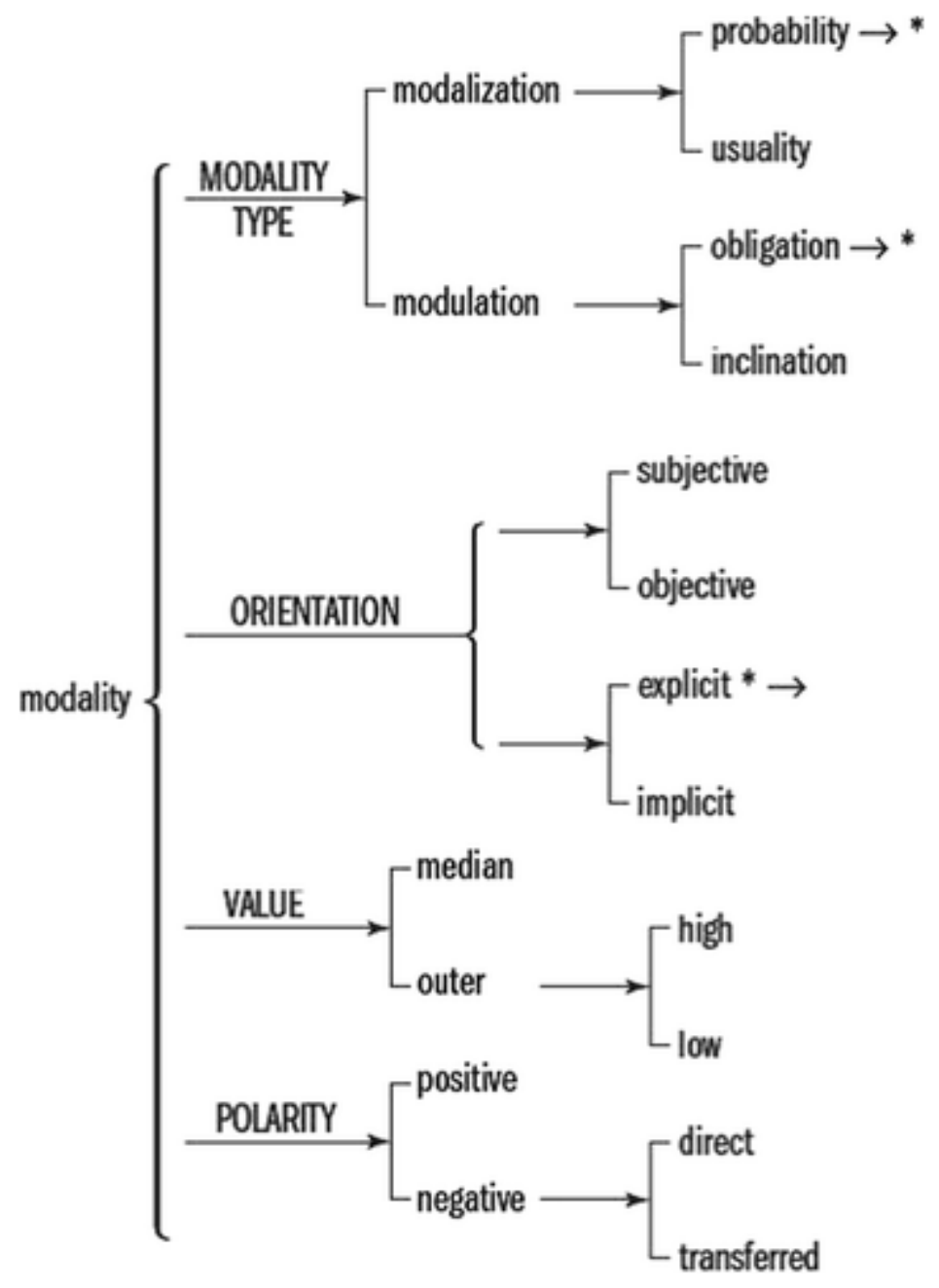

\subsection{System Network of Modality (Halliday \& Matthiessen, 2004)}

It is typically known that the modality in political discourse is very significant usage. We have taken into account two cases for the present study and the analysis is done case by case here onwards.

\subsection{Case-01}

First, we look at the model operators used in the text. Comparatively this text (speech) contains a small number of modal operators that show the speaker's attitude towards the proposition. As a number, it is merely nine modal operators all over the speech. Out of them, the highest occurrence is the median modal operator 'will' which has been used as a positive 
one. High-value positive model operator 'must' occurred only twice over the speech, whereas positive low committed modal operator 'can' also used only twice. The other single occurrence is a positive median modal operator 'would'. As we have already pointed out, there are two types of modalities; modalization and modulation. Modalization indicates probability and usuality, the first adverb serving as an adjunct of modality appeared in this speech is 'always' which shows the usuality. This high-value mood adjunct has appeared twice over the discourse and the first appearance shows the higher commitment of the speaker for the proposition (The commitment of the president to go for sustainable development in Sri Lanka). But, it is usually below the polar value of the expression. The second usage of the same modal adjunct has realized with a modal operator (with 'will') which shows speaker's level of responsibility and commitment towards the local needs in political reforms.

01) In the introduction of political reform and transformation, and in strengthening the national reconciliation process, we will always give prominence to, and respect for local and indigenous philosophy, and the needs and requirements of our people, while protecting the independence, sovereignty and territorial integrity of Sri Lanka.

This type of usages is called combinations; here there is a modal operator and a mood adjunct which shows the usuality. The higher degree of validity of this expression shows the commitment of this speaker towards the proposition.

The explicit subjective modal expression 'I believe' has realized twice over the whole text:

02) I believe that every country must today give importance and priority to addressing these problems

03) We believe, can provide important and useful insight in the quest to seek solutions to many of the problems the world faces today.

When the speaker comes to the second expression, it has generalized by using the first person plural pronoun. High value positive modal operator 'must' has also appeared with the explicit subjective modal expression 'believe' in the first clause, whereas the second has been combined with the positive low-value modal operator 'can'. It shows the lower level of modal responsibility as well. 
Persuasive modal adjunct 'assure' has appeared once in the speech in a declarative form by showing the responsibility towards the proposition.

04) I assure this assembly that we have taken several important steps in our country that are necessary for consolidating democracy, freedom, good governance and the rule of law.

05) We are determined to prevent the recurrence of conflict in my country, Sri Lanka.

Here there is a sort of an offer that represents the degree of inclination and as we clearly established at the beginning, this is modulation. The commitment of this modal expression is high value and the modulation type is inclination.

06) We want to make Sri Lanka an erudite and enlighten nation.

The modulation type is inclination and the degree of modulation is median in this modal expression. In other words, the modal commitment is median of this expression. In addition to these modal operators and modal (actually mood adjuncts) adjuncts, the speech contains several other expressions that have modalized the speech in different ways and some of them are see, intend to and want to. When we look at the whole text of this speech, comparatively modality has not been used as the common political discourse, but the used modal operators and modal adjuncts show a higher level of modal responsibility and commitment.

\subsection{Case-2}

Comparatively, both speeches are small texts and as these two speeches are consecutive speeches of the president after coming to the power, we can see a pattern of modality in his speeches among the international community. Over the second speech, the speaker has used five modal operators recurrently to express the modality; may, will, would, should and must are those modal operators. Over the whole speech, low-value modal operator 'may' has appeared only once and it is also not to show the low validity of proposition but to strengthen the proposition as it has been used with high-value modulation must.

07) Our path forward must be stable and progressive and not one of haste that may be destabilizing, considering the complex and sensitive nature issues that we face.

May is typically used to show the speaker's/writer's assessment of probability towards the 
propositional content and the commitment of this modal verbal operator is low, but it has used negatively to further strengthen the high-value modulation 'must' in the same clause. 'Will' has been used only twice over the speech and some have argued that this does not fall into the category of modal operators as it shows the tense. But, it is a modal expression that contains median value to the proposition. In the places where it has been used, the validity of the proposition is low. 'Would' also appeared only once which is again in median value. The other median value modal operator 'should' has been used twice and the highest percentage of modal operator occurrence is 'must' which contains a higher level of commitment. This modal operator penetrates across the speech ten times.

08) I must inform this assembly.... (This same usage has appeared twice)

09) I must make a special mention....

10) I must emphasize.

11) Must receive our special attention....

12) Discriminations against women still remains a problem in most societies that must be addressed.

13) I must specially emphasize that.....

14) I must emphasize that....

15) I must stress that Sri Lanka....

16) Our path forward must be stable....

What unique is, this modal verbal operator has realized only in positive forms and it has realized only once as an explicit objective modal operator. Objective explicit modality avoids the responsibility to a certain extent in this usage it has not realized in that sense, but it is some sort of prevention from the direct responsibility. Like the other, all clauses show the 
subjective responsibility and high level of commitment this speech can be treated as a unique one in comparing to regular political discourse. In most of the cases, the modal verbal operator 'must' has been used in clause complexes and also they have appeared as modulation.

For the place of 'can' 'be able to' is used and this has been discussed in philosophical semantics too. It was found that there were three clauses where 'be able to' had been used they have realized as low-value modulations. For instance;

17) We look forward to receive greater support from the United Nations Organization for my Government to be able to succeed in our nation building endeavor.

Here, just like 'can', the value of the proposition is low. In other words, it shows an area where the speaker (the president of Sri Lanka) has no control through this modal expression. Another modal expression which contains a higher level of commitment to the made proposal is 'determined to' which have appeared only once in this text;

18) We are determined to build a society where everyone is able to live with freedom and dignity as equal citizens.

Of course, there are two modal expressions in this clause; 'determined to' and 'is able to'. In a way, this is an offer in front of the international community. Apart from these main modal verbal operators and mood adjuncts, there are several other expressions that have been used to modalize the speech. When we closely scrutinize the text, came across the usages such as is essential, bear in mind, fervent hope, it is critical, it is necessary, possibility of reaching, firmly, firmly committed where the speech is modalized in different capacities. Most of the cases, they have been used to persuade the listeners towards the main proposition of his speech at different levels. Thus modality can make a speech fall into the heart of the listener in a loud way and transmit information effectively (Menghe \& Chenglian, 2018).

\section{Conclusion}

As it was pointed out at the outset, the modality has been one of the main language strategies in the political discourse. The present work also falls into political discourse as the selected two speeches are political texts. Comparatively, the speaker has not used a vast number of modal expressions in the first case, but the validity of made propositions remains at a higher level. In the second case, the occurrence of modal verbal operators is high as a percentage and it shows a higher level of commitment. In other words, the speaker's attitude towards the propositions at the time of speaking remains positively. The speaker is certain in his 
statements, particularly in the second speech. Modality refers to the degree of certainty and truth of statements about the world (as quoted in Bankole \& Ayoola, 2014). The speaker's commitment to the validity of messages is obviously manifested in both cases by using modality. As we have highlighted in the discussion, mood and modality are used to investigate the speaker's commitment to the validity of his proposition (Bankole \& Ayoola, 2014). In the first case, the modality is not that powerfully used but in the second case, it is very powerfully used over the speech. The speaker has also become careful not to be direct in a very few places in front of the listeners by using modality. In comparing to the first speech, there is rigorous progress of commitment of the speaker which has realized through modal expressions over the second speech. It shows very clearly what the president has intended to do in the future and what he has already committed to be done. Linguistic modality shows the ways used in everyday language to express levels of commitment to what the communicator intends to do or not to do (Chaiyasat \& Sudajit-apa, 2017) and there are very clear examples of this speaker used modality to show what not to do, particularly in the second text.

\section{Acknowledgment}

We are grateful to our supervisor Prof. Wang Yong who taught us SFL that helped us to develop the theoretical background of this paper while we were studying functional linguistics under his supervision and guidance.

\section{References}

Anicic, A. (n.d.). Modality in Political Discourse: Modalised Utterances in the Obama Romney Election Debate. 259-270. Univerzitet Alfa.

Bankole, M., \& Ayoola, M. (2014). Mood and Modality in Christian Magazines: A systemic Functional Analysis of Christian Women Mirror. International Journal of Humanities and Social Science, 138-149.

Chaiyasat, C., \& Sudajit-apa, M. (2017). Pronouns, Social Actors and Modality Types of Politics: A corpus assisted critical discourse analysis of General Prayuth Chan-o-cha's weekly addresses in times of political crisis. DRAL 3/19th ESEA (pp. 15-34). Thailand: Thammasat University.

De Hoop, H., \& Lestrade, S. (2015). Modality in Lolita. Creative Commons Attribution-Noncommercial.

Dickinson, P. (2009, March). A systemic Linguistic Analysis of Two Prime Ministerial Speeches. Birmingham, UK: The University of Birmingham.

Halliday, M. A. K. (2005). Computational and Quantitative Studies (Collected works of M. A. K. Halliday ed., Vol. 6). (J. J. Webster, Ed.) London \& New York: Continuum.

Halliday, M. A. K. (2007). Language and Society (Vol. Volume 10). (J. J. Webster, Ed.) 
London \& New York: Continuum.

Halliday, M. A. K. \& Matthiessen, C. M. I. M. (2004). An Introduction to Functional Grammar. London: Hodder Arnold.

Lycan, W. G. (1994). Modality and Meaning. Dordrecht, Boston \& London: Kluwer Academic Publishers.

Martin, J. R., \& White, P. R. R. (2005). The Language of Evaluation: Appraisal in Englis. New York: Palgrave Macmillan.

Matthiessen, C. M. I. M., Teruya, K., \& Lam, M. (2010). Key Terms in Systemic Functional Linguistics. London \& New York: Continuum.

Menghe, F., \& Chenglian, B. (2018). Interpersonal Function Analysis of Discourse from the Perspective of Critical Discourse Analysis. Advances in Social Science, Education and Humanities Research, 218-223.

Milkovich, M., \& Sitarica, A. (2017). Epistemic Modality in Political Discourse. Research Result, Social Studies, and Humanities, 75-79. DOI: 10.18413/2408-932X-2017-3-1-75-79.

Thompson, G. (2014). Introducing Functional Grammar, 3rd Edition. Routledge: London \& New York.

Webster, J. J. (2009). Introduction. In M. A. K. Halliday, \& J. J. Webster, Continuum Companion to Systemic Functional Linguistics (pp. 1-12). London \& New York: Continuum.

\section{Appendix}

\section{Appendix 1. $71^{\text {st }}$ Session's speech}

Address by His Excellency Maithripala Sirisena President of the Democratic Socialist Republic of Sri Lanka General Debate of the 71st Session of the United Nations General Assembly New York, 21 September 2016

Good Evening

Blessings of the Triple Gem to all of you

Ayubovan

Vanakkam

As-salamu alaykum

It is an extremely happy occasion for me to participate in this $71^{\text {st }}$ Session of the United Nations General Assembly, as the President of Sri Lanka.

During the past twenty months or so, we have ushered in a new era of transformation in Sri Lanka, and given priority to laying the foundation for the necessary political and economic reforms. 
In particular, we have managed to end the state of fear and doubt that prevailed in Sri Lankan society before my Government came into office, and we have laid the foundation and strengthened the requirements necessary for people living in a democratic society to live with happiness and in freedom, without fear.

The objective of my Government is to make Sri Lanka one of the happiest nations in the world for all the people in my country. Therefore, in consolidating freedom and democracy and achieving economic prosperity, our objective and aspiration is to make the people of Sri Lanka rank among the strongest and most erudite end enlightened in the world.

Poverty is presently a serious challenge throughout the world, including Sri Lanka. Next year, 2017, has been declared as the year of freedom from poverty in my country. We have prioritized economic development, and given prominence to putting in place the necessary requirements for addressing all the problems faced by the people of my country.

Mr. President,

Distinguished Heads of State and Government,

Ladies and Gentlemen,

When working with the United Nations and other organizations as well as other nations, and when working on addressing the requirements of the people of our country, we are committed to always give priority to sustainable development. It is within this framework that we have given prominence to securing the necessary economic benefits for our people. Therefore, we will be mindful to protect our environment, and work within the Agreement reached at the Paris Climate Change Conference as advocated by UN Secretary-General Ban Ki-moon, in making the required transformations in all the necessary fields in our country.

On behalf of the educated young generation in our country, I commit to work towards making Sri Lankan society recognize and give importance to the formulation of new policies aimed at achieving national development and a new production economy, based on knowledge-based economic development, and a green economy.

Mr. President,

Ladies and Gentlemen,

Friends,

As an island nation endowed with ocean resources, the new government hopes giving priority to utilizing ocean resources for implementing a programme of action for development of tourism, fisheries industries and marine research. While advancing free healthcare and free education, we intend to infuse new knowledge into these streams for the development of agriculture and local industries. And, through these steps and the development of local industries, we seek to provide better facilities and improved living standards for the people of our country.

Mr. President, 
We see a disturbing phenomenon in today's world, internationally, in most countries. Societies are afflicted with war and war-like situations, violent extremism, division and hatred. In situations like this, the fundamentals of civilized society and humanity face serious threat. In this context, I believe that every country must today give importance and priority to addressing these problems that have arisen in our societies and work towards developing a society that respects humanity. As a Buddhist country, the values and philosophy in the teachings of Theravada Buddhism too, we believe, can provide important and useful insight in the quest to seek solutions to many of the problems the world faces today. Similarly, I see this present era in the world as one in which the teachings of Christianity, Islam, Hinduism, and other religions and philosophies are important for creating greater understanding. For this, the cooperation of all countries is essential.

In the process of bringing about these changes, there is a serious threat faced by most countries in the world including Sri Lanka to which I would like to draw the attention of the respected General Assembly of the United Nations. This is the problem of drugs that poses a serious threat to human society itself, preying on school-going children and causing much destruction to communities. When this Session of the General Assembly began yesterday, the President of Brazil who made the inaugural address explained in detail, the serious nature of this threat to our societies and communities. While adding my voice to the appeal made by the President of Brazil, I urge the General Assembly of the United Nations to look at developing a strong international framework that is more effective than existing measures that are in place, to eradicate the drug menace that has afflicted our societies and threaten the younger generation, especially children in schools. Such a programme must include plans and efforts to combat this menace at national level in all countries, and at international level.

I assure this Assembly that we have taken several important steps in our country that are necessary for consolidating democracy, freedom, good governance, and the rule of law. I am happy to state that through such transformative steps, we have laid the foundation necessary to forge national reconciliation, and ensure non-recurrence of conflict in our country - my country. As a country that has suffered violent conflict for 30 years, we are drawing from experience and lessons learned to strengthen national reconciliation, and we are determined to prevent the recurrence of conflict in my country, Sri Lanka. We have given priority in this context to consolidate freedom and democracy in our country, and through a strong foundation of national reconciliation forged through unity and friendship among communities, we want to make Sri Lanka an erudite and enlightened nation. For this purpose, I respectfully seek the cooperation of all countries and international organizations.

In the introduction of political reform and transformation, and in strengthening the national reconciliation process, we will always give prominence to, and respect for local and indigenous philosophy, and the needs and requirements of our people, while protecting the independence, sovereignty and territorial integrity of Sri Lanka. This is in line with the importance of recognizing the requirements of the people of my country, specific to Sri Lanka, similar to the need for all the other countries in the world to have such processes in line with local thinking and the specific character of the people in those respective countries. In our journey of carrying out social and political reform in line with the requirements of our people, we seek to do so 
with international assistance and cooperation, and in line with internationally recognized practice to build an enlightened society in my country.

After being entangled in violent conflict for almost 30 years, I seek the cooperation and blessings of the entire international community, to proceed on this journey of strengthening national reconciliation and political reform with wisdom, in an intelligent and prudent manner, with patience and dignity, to accomplish the goals that my treasured Sri Lankan nation, my motherland, seeks.

I value greatly, the cooperation extended to Sri Lanka at all times by the Secretary-General of the United Nations, Mr. Ban Ki-moon, and his officials. During his years in office as Secretary-General, Mr. Ban Ki-moon rendered an invaluable service to all people. He helped us strengthen reconciliation. Internationally, he helped carry out development requirements necessary for all, for the entire world community, and I value his service greatly.

In conclusion, I emphasize the commitment of my Government, at all times, to carry out our responsibilities towards making my country, the Sri Lankan nation, one of the most enlightened nations of the world. For this purpose, we will carry out programmes that empower our youth and our new generations by providing them the necessary knowledge that they require to succeed. In carrying out all these tasks, I ensure that we will act responsibly at all times by building a democratic and free society that can be an example to others, and carry out our responsibilities and obligations towards our people. I end my remarks by respectfully seeking your cooperation and blessings necessary to succeed in this important journey that we have undertaken.

Thank you.

May the Triple Gem bless you!

\section{Appendix 2. $72^{\text {nd }}$ Session's speech}

Address by Maithripala Sirisena, President of the Democratic Socialist Republic of Sri Lanka General Debate of the Seventy-Second Session of the United Nations General Assembly

19 September 2017

United Nations, New York

A very good evening to all of you!

His Excellency the President of the General Assembly

Excellencies

His Excellency the Secretary General of the United Nations

Distinguished Guests

Ladies and Gentlemen

It gives me great pleasure to be able to commence my address to the 72nd Session of the General Assembly while congratulating the newly appointed President and Secretary-General 
of the Organization. In fact, it gives me great pleasure to address this August Assembly for the third time as the Head of State of Sri Lanka.

The theme of this 72nd Session of the General Assembly is 'Focusing on people: striving for peace and a decent life for all on a sustainable planet'.

Today, when we take into consideration the prevailing conditions in the world, this theme is extremely timely.

I was elected President in January 2015. Before being elected, there were a number of promises and pledges that I gave to the beloved people of my country. What I particularly mentioned at the time was that, since the Executive Presidency in Sri Lanka had been vested with more power than that which has been vested in any leader in any other democratic system in the world, once I am elected, I would remove those excessive powers from the Presidency and entrust those powers to the Parliament.

Once I was elected to the Presidency, I have taken steps, while holding office and while enjoying the right to exercise those powers, to in fact shed those powers and transfer those powers to the Parliament. I have thus set an example both to national politics in my country and to international politics, as a leader who has shed power while holding office.

As countries that promote, protect and nurture democracy, it is very important that leaders who are elected to office in democracies take steps to strengthen and protect democracy, exercise power with great responsibility, and use one's authority to build a righteous society.

However, when one observes recent history in the past few decades, one witnesses situations where the reluctance of leaders to leave office has led to the breakdown of peace within those countries, even resulting in the breakdown of peace and the creation of division, disunity and discord between countries in the international arena as well. We have the benefit of several such examples from history.

I must inform this Assembly, that, in my country, we have succeeded in consolidating democracy, and removing from office political groups that wielded extreme, excessive power and autocratic governance. During the last two-and-a-half years, we have succeeded in our journey of re-establishing and restoring the freedom of the people, protecting human rights and nurturing fundamental rights.

In the development journey of our nation, this year, 2017, was named as the 'Year for Alleviation of Poverty'. Just like my country, the entire global community is today engaged in efforts to eradicate poverty. Having named 2017 as the year for freedom from poverty, we initiated and launched development projects in Sri Lanka this year to strengthen the domestic economy. As all of you in the international community are well aware, the conflict that prevailed in Sri Lanka for 30 years affected our economy adversely and resulted in the weakening of our economy. We succeeded in defeating the separatist terrorist movement within our country and in initiating peace, establishing democracy and taking our country forward as a peaceful and free nation. For this purpose, drawing from lessons learned from the conflict and economic disadvantages of conflict, we turned a new page, towards a forward looking journey to achieve the Sustainable Development Goals, and strengthening the 
domestic economy including local agriculture and industries.

In working towards realizing the Sustainable Development Goals, my government has accorded priority to conservation of the environment. I must make special mention of the fact that today, just as my own country, the entire world, including the United States of America, is facing difficulties and challenges as a result of climate change. In this context, it is essential that the international Agreement that we reached in Paris, and the unity that we achieved internationally by signing and ratifying the Agreement is carried forward through its implementation. This is an important goal that is before the world community today that I must emphasize. It is vital that we bear in mind the importance of implementation of the Paris Agreement in the interest of humankind as well as the eco-systems and all living beings on this planet.

Under the national programme for alleviation of poverty, my government commenced a special programme named "Grama Shakthi” ("Strengthening the Villages").

Similarly, we have launched a clear economic policy and plan up to the year 2025 named 'Vision 2025'. Aimed at strengthening the local economy, local agriculture, and alleviation of poverty, it is our fervent hope that the economic development programme 'Vision 2025' will enrich our country, infusing it with new energy and prosperity.

Mr. President,

I must make special mention of the fact that both in my country and in countries all over the world, children are today faced with several problems and challenges. In my country, in order to protect children, we have initiated a broad national programme under the theme of "Protecting Children". Protecting children from drugs and various forms of abuse is important, and must receive our special attention at national and international level. It is critical that such programmes are drawn up with clear targets for implementation at both national and international level.

The world is seized of the need for protection and promotion of Women's Rights. Achieving gender parity is still a challenge in most countries and in most societies. Discrimination against women still remains a problem in most societies that must be addressed. In my country, over $52 \%$ of the population are women. Women's Rights are guaranteed through amendments to our Constitution. Similarly, my Government has included in the new Constitutional amendments, provision to ensure that $25 \%$ of the list of candidates at elections should comprise of women.

Protection of children, protection of women's rights, and steps to combat drug abuse are programmes that we have started at national level. Similarly, it is important that the United Nations too pays attention to the need for an international, world-wide programme to eradicate illegal drugs and deal with the challenges of drug abuse. This is important in the interest of the entirety of humankind. Accordingly, all countries and all societies, from school children onwards should be made conscious of the need to combat and eradicate the scourge of drug abuse that poses a significant challenge to all of humanity. It is necessary to explore the possibility of reaching an international Plan of Action through consensus, towards this 
end.

When I was elected to office in 2015 after the end of a nearly three-decade long conflict, there were two main problems or challenges that we had to face. One of the main problems was the severe debt burden. The other problem was the issue that the previous government had faced in dealing with the implementation of Human Rights Council resolutions pertaining to allegations of violations of human rights during the conflict.

Through the programme that we have launched to strengthen the domestic economy, we have taken steps to establish target oriented measures for reducing the debt burden, including through attracting foreign investment. Similarly, my Government is committed to taking steps, as a priority, to find solutions to the matters of concern that have received the attention of the Human Rights Council. While we have taken steps towards consolidating democracy and protecting human rights and fundamental freedoms during the last two-and-a-half years and successfully established a democratic society, we will continue to work in the future towards the further strengthening of these important attributes.

I must especially emphasize that my Government is firmly committed to strengthen national reconciliation, and ensure that all the people living in my country, speaking different languages, and of different religions are able to live in unity, without fear, suspicion, hatred and anger. We are determined to build a society where everyone is able to live with freedom and dignity as equal citizens. My Government is committed to achieve these ends in a holistic manner through the strengthening of the domestic economy and the creation of prosperity and taking steps to create a disciplined and righteous society. Consolidating the Rule of Law and righteousness are priorities to which my Government remains firmly committed.

Mr. President,

I must emphasize that, at this important time in my country's journey, when we are taking progressive measures to strengthen democracy, human rights and fundamental freedoms, and we are moving forward forging friendships and closer engagement with the international community, we look forward to receive greater support from the United Nations Organization for my Government to be able to succeed in our nation-building endeavour.

Sri Lanka has been a member of the United Nations for almost 62 years. I must stress that Sri Lanka, as a member of the UN, is firmly committed to abiding by its Charter, and the Conventions and Rules and Regulations and decisions of the United Nations at all times.

Accordingly, we seek the respectful support of all, as we take steps in a progressive manner, to address allegations and implement resolutions, while protecting the independence and sovereignty of my country. Some expect quick action and short-sighted, short-term solutions. As a country which has suffered an almost 30-year-long conflict, I urge the respectful support of all, in ensuring the success of the journey we have embarked upon to unite the people who were torn by division in my country, to build feelings of unity and compassion, to dispel fear, suspicion, anger and hatred and take forward the beloved people of my country and strengthen and rebuild my beloved motherland as a strong and prosperous democracy. Our path forward must be stable and progressive and not one of haste that may be destabilizing, 
considering the complex and sensitive nature of issues that we face.

I once again urge the United Nations and the international community to support and assist the journey that we have undertaken to ensure non-recurrence of conflict in my country, to forge unity and friendship among all communities in my country, to take my country forward as a nation that is reconciled and all citizens of all communities, speaking different languages, of different religions, are united and bound by feelings of humanity. I seek your support for the development efforts we have undertaken that are essential for the reconciliation efforts to succeed and ensure non-recurrence of conflict and our vision of a nation that is righteous, prosperous and democratic, to succeed, as an example to other countries that are also recovering from conflict.

Mr. President,

Mr. Secretary General,

I conclude my remarks, wishing you the very best and assuring you of Sri Lanka's cooperation.

Thank you.

May the Triple Gem Bless You.

\section{Copyright Disclaimer}

Copyright for this article is retained by the author(s), with first publication rights granted to the journal.

This is an open-access article distributed under the terms and conditions of the Creative Commons Attribution license (http://creativecommons.org/licenses/by/3.0/). 